\title{
Enzymatic Hydrolysis and Fermentation Strategies for the Biorefining of Pine Sawdust
}

\author{
Carolina Mónica Mendieta, Fernando Esteban Felissia, Ana María Arismendy, \\ Julia Kruyeniski, and María Cristina Area*
}

\begin{abstract}
This work aims to evaluate second-generation bioethanol production from the soda-ethanol pulp of pine sawdust via two strategies: separate hydrolysis and fermentation and simultaneous saccharification and fermentation. A kinetics study of the enzymatic hydrolysis of separate hydrolysis and fermentation was included as a design tool. Three sodaethanol pulps (with different chemical compositions), Cellic ${ }^{\circledR}$ Ctec2 cellulolytic enzymes, and Saccharomyces cerevisiae IMR 1181 (SC 1181) yeast were employed. The obtained kinetic parameters were as follows: an apparent constant $(k)$ of $11.4 \mathrm{~h}^{-1}$, which represents the link frequency between cellulose and cellulase; a Michaelis-Menten apparent constant $\left(K_{\mathrm{M}}\right)$ of $23.5 \mathrm{gL}^{-1}$, that indicates the cellulose/cellulase affinity; and the apparent constant of inhibition between cellulose-glucose and cellulase $\left(K_{\mathrm{I}}\right)$, which was $2.9 \mathrm{gL}^{-1}, 3.1 \mathrm{gL}^{-1}$, and $6.6 \mathrm{gL}^{-1}$ for pulps 1, 2, and 3, respectively. The kinetic model was applicable, since the calculated glucose values fit the experimental values. High bioethanol yields were obtained for pulp 3 in the separate hydrolysis and fermentation and simultaneous saccharification and fermentation processes $(89.3 \%$ and $100 \%$ after $13 \mathrm{~h}$ and $72 \mathrm{~h}$, respectively).
\end{abstract}

Keywords: Biorefinery; Pine sawdust; Bioethanol; Kinetic model; Michaelis-Menten

Contact information: IMAM, UNaM, CONICET, FCEQYN, Programa de Celulosa y Papel (PROCYP), Félix de Azara 1552, Posadas 3300, Argentina; *Corresponding author: cristinaarea@ gmail.com

\section{INTRODUCTION}

There is a worldwide movement to replace fossil fuels with renewable energy sources due to their negative impact, primarily their greenhouse gas emissions. Therefore, new alternatives for the production of biofuels are sought, due to their numerous advantages, e.g., sustainability, reduction of gases contributing to climate change, and the possibility of improving social-regional systems, among others (Hahn-Hagerdal et al. 2006; Posen et al. 2014). In recent years, large quantities of $1 \mathrm{G}$ (first generation) bioethanol have been produced from sugarcane and corn, generating the food-versus-fuel debate (Chu et al. 2012). Meanwhile, lignocellulosic sawdust and shavings represent an abundant and low-cost source that is not fully exploited. In this sense, biorefineries can provide a solution for their final disposal (Rodríguez et al. 2017). In the frame of a biorefinery, second-generation bioethanol can be used as fuel (Clauser et al. 2021) or to obtain bioethylene and biopolythylene (Mendieta et al. 2019, 2021), while high-value products can be obtained from other fractions.

The primary economic activity of the northwest region of Argentina (NEA) is the forest industry, which contributes to large amounts of waste generation (Brodin et al. 2017). In particular, the sawdust from slash and loblolly pines is one of the chief residues produced by the wood industry in the NEA region, generating approximately 212 million 
tons of this wood waste in 2018 (Laharrague 2018).

Cellulose is the most abundant organic component of lignocellulosic biomass. It is also a virtually inexhaustible source of renewable bioenergy (Alzate and Toro 2006). Thus, the hydrolysis of cellulose has gained considerable interest in the past decades because it can provide glucose, which serves as a raw material for bioethanol and other chemical products (Yang et al. 2011). In addition, the acid-catalyzed hydrolysis process is faster and more effective than the enzymatic one. However, enzymatic hydrolysis is preferred for bioethanol production because it offers a bioconversion process under milder operating conditions (Hou et al. 2019).

Due to its high selectivity and efficiency, biochemical conversion is the usual technique for producing bioethanol from lignocellulosic materials (Vallejos et al. 2017). Biomass pretreatment is required in $2 \mathrm{G}$ bioethanol production to reduce the lignin content, which inhibits the access of enzymes to the material (Vallejos et al. 2017). Besides, it releases the cellulose present in the lignin-carbohydrate matrix, which facilitates depolymerization of the carbohydrates to produce simple sugars via enzymatic hydrolysis and glucose fermentation to bioethanol (Zhu et al. 2011).

The pretreatment is selected according to the physical and chemical characteristics of the raw material. Organosolv pretreatments have been especially studied for pine because most lignin and hemicelluloses are dissolved in the process, facilitating biomass fractionation (Sannigrahi et al. 2010). Soda-ethanol pretreatment improves the hydrolysis performance, since alkali is one of the most effective agents for biomass swelling (Kruyeniski et al. 2019). Extracting the highest lignin amount possible and opening the pores of the fibers increases the accessibility of the enzymes in the remaining components for the subsequent processing steps (Araque et al. 2008; Yu et al. 2011). In addition, their extraction increases the surface area, which facilitates the accessibility of enzymes and improves the enzymatic conversion (Area and Vallejos 2012; Das et al. 2019).

Enzymatic hydrolysis follows the pretreatment. It is a catalytic process in which enzymes act synergistically to produce glucose monomers by bond cleavage between polysaccharides (Taherzadeh and Karimi 2007). It is carried out under mild conditions (generally at a pH of 4.5 to 5.0 and at temperatures between 40 to $50{ }^{\circ} \mathrm{C}$ ) (Chang and Holtzapple 2000; Yang and Fang 2015).

The kinetic model of enzymatic hydrolysis plays a relevant role in describing the performance and attributes of the process and can easily be used to control and predict the results (Cekmecelioglu and Uncu 2013). In addition, a kinetic model for the bioconversion process that appropriately describes the enzymatic reaction is essential for the reactor design (Yang and Fang 2015). The Michaelis-Menten model is one of the best-known approaches to enzyme kinetics in biochemistry (Tomczak and Węglarz-Tomczak 2019). Its equation is valuable because it provides a tool for understanding enzymatic reactions (Roskoski 2015). Furthermore, setting the kinetic reaction velocity is necessary to obtain the fundamental parameters that describe the model (Li et al. 2004).

Following the saccharification, fermentation with yeasts is traditionally performed with Saccharomyces cerevisiae. It is the most used microorganism in industrial fermentation due to its capability for efficiently fermenting glucose to bioethanol. This yeast is considered a GRAS (generally recognized as safe) and an effective microorganism because of its high productivity, tolerance to ethanol, workable acidic $\mathrm{pH}$ range, and temperature range, between 25 and $35^{\circ} \mathrm{C}$ (Olsson and Hahn-Hägerdal 1996).

The usual strategies are separate hydrolysis and fermentation (SHF) and simultaneous saccharification and fermentation (SSF) (Balat 2011). In the first method,

Mendieta et al. (2021). "Pine hydrolysis, fermentation," BioResources 16(4), 7474-7491. 7475 
both stages are carried out separately under their optimum conditions. Such an approach has the disadvantage of generating inhibition products, e.g., glucose for hydrolysis and ethanol for fermentation (Araque et al. 2008). In the simultaneous process, both hydrolysis and fermentation are carried out in a single reactor. Its primary advantage is that the glucose produced during hydrolysis is immediately consumed by the yeasts, avoiding sugar accumulation, and reducing possible bacterial contamination (Area and Vallejos 2012). In addition, the cost is reduced due to the use of a single reactor, making the processing more efficient (Arismendy et al. 2018).

This work aims to evaluate second-generation $(2 \mathrm{G})$ bioethanol production using both fermentation strategies, i.e., separate hydrolysis and fermentation (SHF) and simultaneous hydrolysis and fermentation (SSF), with soda-ethanol pine sawdust pulps, including a kinetics study of the enzymatic hydrolysis in SHF as a design tool. In addition, this study offers tools for deciding which process to use according to the available equipment.

\section{EXPERIMENTAL}

\section{Materials and Methods}

The industrial sawdust mix of Pinus elliottii and Pinus taeda was provided by a sawmill in Misiones, Argentina.

The soda-ethanol pretreatment was selected considering the physical and chemical characteristics of the raw material to extract the lignin and hemicelluloses. The conditions were chosen based on preliminary results to obtain pulps with different lignin contents. Three soda-ethanol pulps with different chemical compositions were used to assess the suitability of the applied treatments and the kinetic model.

The operating conditions of the soda-ethanol pretreatment were as follows: a liquorto-wood ratio ( $\mathrm{L}: \mathrm{W})$ of $5.44: 1$, a maximum temperature of $170{ }^{\circ} \mathrm{C}$, a time-to-maximum temperature of $60 \mathrm{~min}$, and the $\mathrm{EtOH}: \mathrm{H}_{2} \mathrm{O}$ ratio (35\% to $\left.65 \% \mathrm{v} / \mathrm{v}\right)$ was constant in all cases. The variable conditions, the $\mathrm{NaOH}(\% \mathrm{w} / \mathrm{w})$ and time, were as follows: $19.0 \% \mathrm{w} / \mathrm{w}$ and 60 min for experiment 1 (pulp 1); $19 \% \mathrm{w} / \mathrm{w}$ and $100 \mathrm{~min}$ for experiment 2 (pulp 2), and 23.3\% w/w and $140 \mathrm{~min}$ for experiment 3 (pulp 3).

Cellic ${ }^{\circledR}$ CTec 2 commercial enzymes provided by Novozymes were used for the enzymatic hydrolysis. The strains of Saccharomyces cerevisiae IMR 1181 (SC 1181) applied during the fermentation process were donated by a research center, the Institute of Modeling and Technological Innovation IMIT (UTN-CONICET), Resistencia, Argentina.

\section{Characterization of the Substrate and Hydrolysates}

Sawdust's chemical composition was determined in previous work (Imlauer et al. 2021). Pine sawdust and pulps (substrate) were characterized according to NREL (National Renewable Energy Laboratory) standards, including total solid and moisture (NREL/TP510-42621) (Sluiter et al. 2008), and structural carbohydrates, and lignin (NREL/TP-51042618) (Sluiter et al. 2004). HPLC with a SHODEX SP810 column was used to determine the carbohydrates content (glucan, xylan, mannan, galactan, and arabinan) in the pretreated material. The operational conditions used were water as eluent, $0.6 \mathrm{~mL} / \mathrm{min}, 85^{\circ} \mathrm{C}$, and refractive index detector.

The quantification of the homopolymers, i.e., glucans, xylans, galactans, mannans, and arabinans in the solid portion was carried out by multiplying sugars by the 
stoichiometric factors of hydrolysis, i.e., 0.88 (132/150) for sugars with five carbons (xylose and arabinose) and 0.90 (162/180) for sugars with six carbons (glucose, mannose, and galactose).

The quantification of glucose, total sugars, and bioethanol was carried out via HPLC liquid chromatography (Waters Corp., Milford, MA), using an AMINEX-HPX97H column (BIO-RAD) with the following chromatographic conditions: an eluent of $4 \mathrm{mM}$ of $\mathrm{H}_{2} \mathrm{SO}_{4}$, a flow of $0.6 \mathrm{~mL} / \mathrm{min}$, a temperature of $35^{\circ} \mathrm{C}$, and a refractive index detector and diode array.

\section{Enzymatic Hydrolysis}

Separate hydrolysis and fermentation (SHF) strategy

The cellulase activity was determined in terms of "filter paper units" (FPU) according to the NREL/TP-510-42628 standard (Adney and Baker 2008) and by $\beta$ glucosidase (EC 3.2.1.21), according to its ability to hydrolyze 4-nitrophenyl $\beta$-Dglucopyranoside ( $\mathrm{p}-\mathrm{NPG}$ ) to 4-nitrophenol (p-NP). This method consists of adding $0.5 \mathrm{~mL}$ of different enzymes concentrations to $2 \mathrm{~mL}$ of a $1 \mathrm{mmol} / \mathrm{L} \mathrm{p}-\mathrm{NPG}$ solution, incubating for $30 \mathrm{~min}$ at a temperature of $50{ }^{\circ} \mathrm{C}$, and then stopping the reaction with $2.5 \mathrm{~mL}$ of $\mathrm{Na}_{2} \mathrm{CO}_{3}$. Finally, the absorbance was measured at $400 \mathrm{~nm}$ and expressed in IU (international unit) (Matsuura et al. 1995).

The solid material was subjected to saccharification with Cellic ${ }^{\circledR}$ CTec 2 enzymes (provided by Novozymes) according to NREL-LAP standards (NREL/TP-510-42629) (Resch et al. 2015). The method was modified, changing the enzymatic load to $30 \mathrm{FPUg}-$ 1 of glucans and adding 0.3 gL- 1 of the surfactant Tween 80 to improve the efficiency of the process (Pabón et al. 2020). The enzymatic hydrolysis conditions taken from Arismendy et al. (2019) involved 1\% hydrolyzable cellulose (dry matter) suspended in 50 $\mathrm{mL}$ of $0.05 \mathrm{M}$ sodium citrate (a pH of 5) and $40 \mathrm{~mL}$ of distilled water, at $130 \mathrm{rpm}$ and a temperature of $37^{\circ} \mathrm{C}$, in a $200 \mathrm{~mL}$ Erlenmeyer flask. Samples were taken between $3 \mathrm{~h}$ and $9 \mathrm{~h}$ for $48 \mathrm{~h}$. The experiments were performed in duplicate.

The hydrolysis yield (digestibility) was calculated according to Eq. 1,

$$
\text { EH yield }(\%)=\frac{\text { glucose }(g) * 0.9}{\text { glucans in the material }(g)} * 100
$$

where $\mathrm{EH}$ yield (\%) is the enzymatic hydrolysis yield (digestibility), 0.9 is the stoichiometric factor, and the glucans correspond to the original amount in the material.

\section{Kinetic study}

This work used a simplified kinetic model proposed by Li et al. (2004), considering a pseudo-homogeneous Michaelis-Menten model. A simplified scheme of the reaction mechanism is shown in Fig. 1.

$$
\text { Cellulose }(\mathrm{S}) \stackrel{E G / C B}{\longrightarrow} \text { Oligosaccharide }(\mathrm{O}) \stackrel{B G}{\longrightarrow} \text { Glucose }(\mathrm{G})
$$

Fig. 1. Scheme of the reaction mechanism of the obtaining of glucose from cellulose

The reaction mechanism first comprises a heterogeneous reaction involving the insoluble substrate $(\mathrm{S})$ and the enzymatic solution to produce soluble oligosaccharides $(\mathrm{O})$. In this stage, which is considered as governing the overall reaction rate, the endoglucanases (EG) act synergistically by hydrolyzing the $\beta-(1,4)$ glycosidic bonds, which results in 
generating non-reducing chain ends, and the cellobiohydrolases $(\mathrm{CBH})$ hydrolyze cellobiose, which act on non-reducing ends. The second step, which is much faster than the first one, is a homogeneous reaction of the oligosaccharides to obtain glucose $(G)$. In this hydrolysis process, primarily catalyzed by $\beta$-glucosidase (BG), the formed oligosaccharides produce cellobiose. The sum of the oligosaccharides and glucose reactions generates products that inhibit the cellulase enzymes. If one makes the simplifying assumption that this is the only inhibitory effect, then the simplified reaction scheme is reduced to the following (as shown in Fig. 2).

$$
\mathrm{S} \stackrel{E G / C B H / B G}{\longrightarrow} \mathrm{T}
$$

Fig. 2. Simplified reaction scheme of the obtaining of total sugars from cellulose

The pseudo-homogeneous model to determine the rate of total sugar $(T)$ production over time corresponds to the difference between the maximum amount produced during the reaction $\left(T_{\infty}\right)$ and the amount present at time $t$. The rate of glucose production over time is evaluated through this model, replacing the term $T$ with $G$ in the equation proposed by Li et al. (2004), as shown in Eq. 2,

$$
\frac{\mathrm{d} G}{\mathrm{~d} t}=\frac{k E_{0}\left(G_{\infty}-G\right)}{K_{M} *\left[1+\left(\frac{1}{K_{I}}\right) T\right]+0,9\left(G_{\infty}-G\right)}
$$

where $G_{\infty}$ is the maximum glucose value reached during the reaction $\left(\mathrm{gL}^{-1}\right), 0.9$ is a stoichiometric factor (relationship between the molecular weight of a unit of glucose in cellulose and the molecular weight of glucose), $k$ is an apparent constant representing the link frequency between cellulose and cellulases $\left(\mathrm{h}^{-1}\right), K_{\mathrm{M}}$ is a Michaelis-Menten apparent constant representing the affinity between cellulose and cellulases $\left(\mathrm{gL}^{-1}\right), K_{\mathrm{I}}$ is the apparent constant of inhibition between cellulose-glucose and cellulases $\left(\mathrm{gL}^{-1}\right)$, and $E_{0}$ is initial enzyme concentration $\left(\mathrm{gL}^{-1}\right)$.

For a given cellulase system, the $k$ values could depend on the properties of the substrate because of the contact efficiency between the insoluble substrate and the cellulases solution. It also could be a function of the various operating conditions, e.g., the reactor type and size, mixing, and substrate concentration. It was also suggested that the values of $G_{\infty}$ could depend on the same variables as above and that $K_{\mathrm{M}}$ and $K_{\mathrm{I}}$ are independent of the operating variables. Therefore, these values change when changing the enzyme or the substrate, and the whole procedure must be repeated (Albernas-Carvajal et al. 2015).

\section{Fermentation}

Separate hydrolysis and fermentation (SHF) strategy

The fermentation with yeast (Saccharomyces cerevisiae IMR 1181 (SC 1181)) was performed following the NREL-LAP standards (NREL/TP-510-42630) (Dowe and McMillan 2008), by adjusting the proportion of YPD (yeast Extract-Peptone-Dextrose) medium and micronutrients to improve the fermentative activity of the yeast in the process. The YPD medium was prepared in a $200 \mathrm{~mL}$ Erlenmeyer flask, with $10 \mathrm{gL}^{-1}$ of yeast extract and $20 \mathrm{gL}^{-1}$ of peptone as well as $20 \mathrm{gL}^{-1}$ of dextrose, $0.605 \mathrm{gL}^{-1}$ of phosphate, $0.16 \mathrm{gL}^{-1}$ of chloride of ammonium, $0.10 \mathrm{gL}^{-1}$ of magnesium sulfate, and distilled water for a total volume of $100 \mathrm{~mL}$. It was sterilized in an autoclave at $121^{\circ} \mathrm{C}$ for $30 \mathrm{~min}$. A pre-inoculum 
was performed to increase the cell growth, adding $20 \mathrm{~mL}$ of the YPD medium and the yeast to a $70 \mathrm{~mL}$ Erlenmeyer flask and letting the culture in a thermal bath at $37^{\circ} \mathrm{C}$ at $180 \mathrm{rpm}$ until a constant cell amount was obtained, measured by optical density. Finally, the YPD medium was completely inoculated for $24 \mathrm{~h}$ in a thermal bath under the same conditions.

For the fermentation experiments, $90 \mathrm{~mL}$ of the hydrolyzed sugars, $10 \mathrm{~mL}$ of the inoculum, $0.5 \mathrm{gL}^{-1}$ of yeast extract, and $1 \mathrm{gL}^{-1}$ of peptone were added to $200 \mathrm{~mL}$ Erlenmeyer flasks in a thermal bath stirred at $130 \mathrm{rpm}$. Air traps were used to prevent the entry of oxygen into the system as well as allow the release of the $\mathrm{CO}_{2}$ produced by the yeast. The experiments were performed in duplicate.

\section{Simultaneous saccharification and fermentation (SSF) strategy}

The solid material was subjected to fermentation with Saccharomyces cerevisiae IMR 1181 (SC 1181) yeast according to NREL-LAP 510-42630 (Dowe and McMillan 2008). The SSF process was carried out in $200 \mathrm{~mL}$ Erlenmeyer flasks using $1 \%$ hydrolyzable cellulose (percentage of dry matter) suspended in $50 \mathrm{~mL}$ of $0.05 \mathrm{M}$ sodium citrate (a pH of 5), $40 \mathrm{~mL}$ of distilled water, $10 \mathrm{~mL}$ of inoculum, $0.028 \mathrm{~mL}$ of surfactant, $30 \mathrm{FPUg}^{-1}$ of Cellic ${ }^{\circledR}$ Ctec 2 enzyme-substrate, $0.5 \mathrm{gL}^{-1}$ of yeast extract, and $1 \mathrm{gL}^{-1}$ of peptone (a total of $100 \mathrm{~mL}$ ), and using the same operating conditions as the SHF process.

For both strategies, the fermentation yield $\left(Y_{\mathrm{P} / \mathrm{T}}\right)$ was calculated as the efficiency of fermentation (practical ethanol obtained against theoretical ethanol), and the bioethanol productivity $\left(P_{\mathrm{p} / \mathrm{t}}\right)\left(\mathrm{gL}^{-1} \mathrm{~h}^{-1}\right)$ was calculated as the relationship between the obtained ethanol concentration divided by the time employed for hydrolysis and fermentation.

\section{RESULTS AND DISCUSSION}

\section{Characterization of the Substrate}

Sawdust chemical composition (\% on oven-dry material) was $40.90 \%$ Glucans, 7.45\% Xylans, 2.58\% Galactans, 14.80\% Mannans, 0.77\% Arabinans, and 29.20\% Lignin.

The composition of the soda-ethanol pulps is shown in Table 1. Depending on the conditions, this treatment resulted in the extraction of a high amount of lignin (especially in experiment 3), increasing the enzymes' access to the material. Results were similar to those in Schenck et al. (2013), who used Nordic pine (Pinus sylvestris) pretreated under similar conditions obtaining a low lignin content in the pulps after alkaline pretreatment ( $1.6 \%$ to $4.1 \%)$.

Table 1. Chemical Composition of the Solid Fraction Obtained by the SodaEthanol Pretreatment

\begin{tabular}{|c|c|c|c|c|c|c|c|}
\hline Pulp & $\begin{array}{c}\text { Glucans } \\
(\% \circ \mathrm{dm})\end{array}$ & $\begin{array}{c}\text { Xylans } \\
(\% \text { odm })\end{array}$ & $\begin{array}{c}\text { Galactans } \\
(\% \text { odm })\end{array}$ & $\begin{array}{c}\text { Mannans } \\
(\% \text { odm })\end{array}$ & $\begin{array}{c}\text { Lignin } \\
(\% \text { odm })\end{array}$ & $\begin{array}{c}\text { Delignification } \\
(\%)\end{array}$ & $\begin{array}{c}\text { Pulp yield } \\
(\%)\end{array}$ \\
\hline 1 & 67.35 & 9.71 & 1.23 & 7.38 & 10.18 & 82.6 & 49.86 \\
\hline 2 & 73.51 & 8.64 & 0.73 & 7.58 & 7.04 & 88.8 & 46.49 \\
\hline 3 & 80.18 & 7.20 & 0.29 & 8.40 & 3.67 & 94.9 & 40.48 \\
\hline
\end{tabular}

Mendieta et al. (2021). "Pine hydrolysis, fermentation," BioResources 16(4), 7474-7491. 7479 


\section{Enzymatic Hydrolysis}

The yield of sugar via the separate hydrolysis and fermentation (SHF) strategy

Figure 3 shows the enzymatic hydrolysis yields and the equivalent glucose concentration in the liquid (in the secondary axis) versus time. Contrasting this data with the chemical composition of each pulp, the influence of the lignin content and glucans content on the enzymatic hydrolysis yield was notable. Compared to pulp 1, pulp 3 presented the highest $\mathrm{EH}$ percentage in less time, obtaining $100 \% \mathrm{EH}$ in $48 \mathrm{~h}$, confirming that the lignin content prejudices the access of the enzyme complex to the material and, therefore, the digestibility of cellulose.

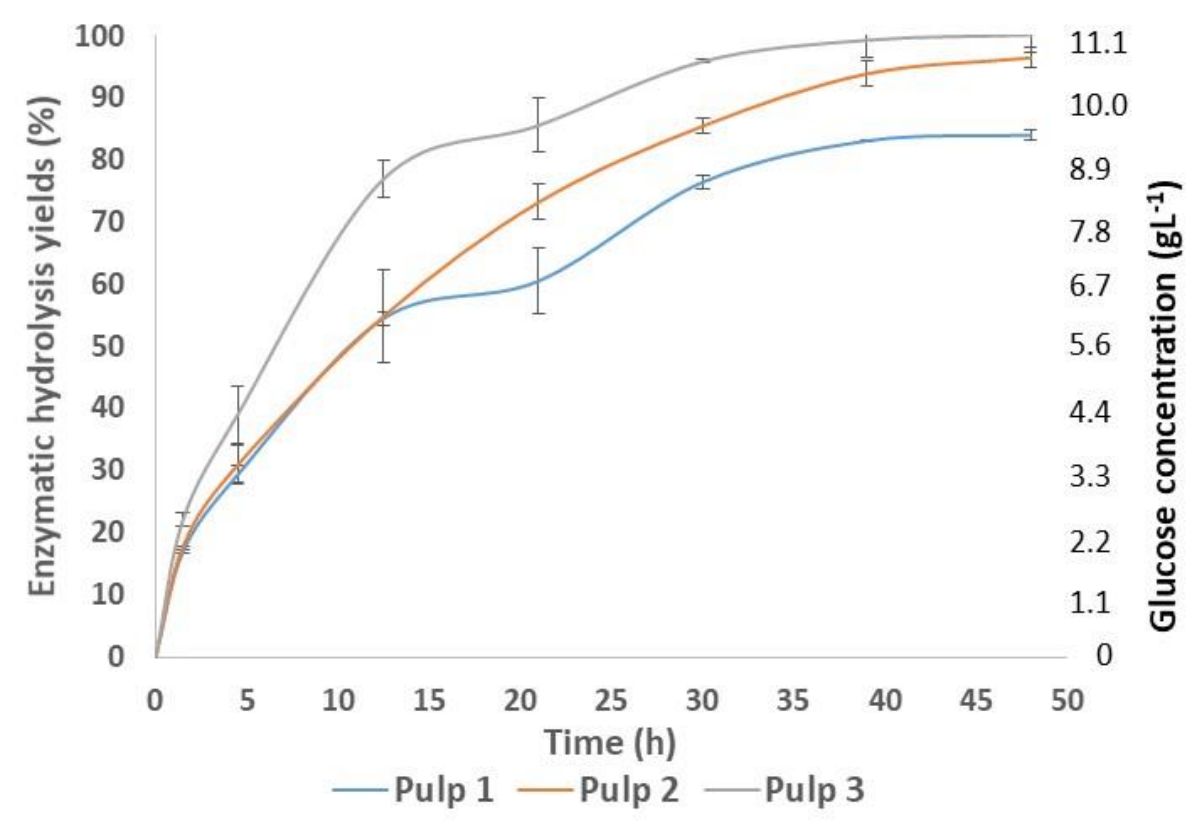

Fig. 3. Enzymatic hydrolysis yields for the soda-ethanol pulps with three different chemical compositions (pulp 1 being the one with the highest lignin content and the lowest glucan content)

These results are comparable with those obtained by Kruyeniski (2017), who achieved an enzymatic hydrolysis yield of $91.1 \%$ using a mixture of Pinus elliottii and Pinus taeda sawdust pretreated with soda-ethanol $(50 \mathrm{~g} / \mathrm{L}$ of $\mathrm{NaOH}, 35$ to 65 ratio of ethanol to water for $60 \mathrm{~min}$ at temperature of $170^{\circ} \mathrm{C}$ ). Kruyeniski (2017) used an enzymatic complex of cellulases from Trichoderma reesei and cellobiase from Aspergillus niger (both provided by Sigma Aldrich). In another work, the authors reported regression models comparing the alkaline treatments and the acid treatments, concluding that pretreatments that promote high lignin removal increase in the enzymatic hydrolysis yield (Kruyeniski et al. 2019).

\section{Parameters of the pseudo-homogeneous Michaelis-Menten model}

Applying the methodology proposed by Li et al. (2004), the glucose values $\left(\mathrm{gL}^{-1}\right)$ obtained in the enzymatic hydrolysis were plotted $v s$. the time (h) at $1 \%$ consistency as a calculation basis (Fig. 3).

In the initial stage of the reaction $(t \rightarrow 0, G \rightarrow 0)$, the total formed sugars can be neglected so that Eq. 2 can be simplified, as shown in Eq. 3, 


$$
\left(\frac{d G}{d t}\right)_{t \rightarrow 0}=\frac{k E_{0} G_{\infty}}{K_{M}+0.9 G_{\infty}}
$$

The initial rate $(\mathrm{d} G / \mathrm{d} t)_{t \rightarrow 0}$ was determined as the mean production rate of glucose during the initial reaction period up to $1.5 \mathrm{~h}$. Following the methodology proposed by $\mathrm{Li}$ et al. (2004), $G_{\infty}$ was determined for experiments 1, 2, and 3, which were $6.73 \mathrm{gL}^{-1}, 7.75$ $\mathrm{gL}^{-1}$, and $9.51 \mathrm{gL}^{-1}$, respectively, in $21 \mathrm{~h}$. The graphical determination of $k$ and $K_{\mathrm{M}}$ is presented in Fig. 4 for an initial enzyme concentration $\left(E_{0}\right)$ of $0.476 \mathrm{gL}^{-1}$.

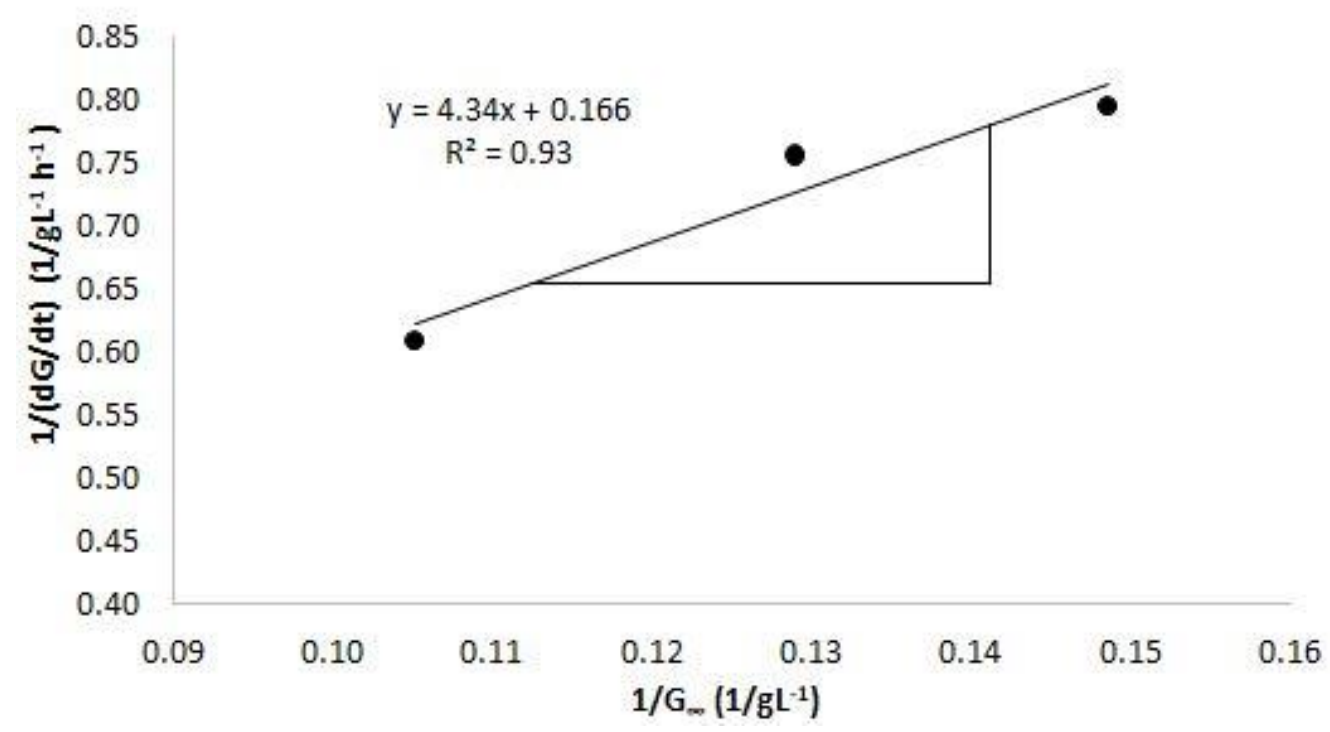

Fig. 4. Determination of $K_{\mathrm{M}}$ and $k$

Finally, $1 /(\mathrm{d} G / \mathrm{d} t)_{\mathrm{t} \rightarrow 0} v s .1 / G_{\infty}$ was plotted to obtain the slope and the intercept to determine the values of $K_{\mathrm{M}}$ and $k$, which were $23.5 \mathrm{gL}^{-1}$ and $11.4 \mathrm{~h}^{-1}$, respectively.

The $K_{\mathrm{M}}$ value provides an idea of the affinity of the enzyme for cellulose. At a lower $K_{\mathrm{M}}$ (higher affinity), the enzyme-cellulose complex is stable. On the contrary, if the $K_{\mathrm{M}}$ is large, the enzyme-substrate complex is unstable, indicating a low affinity for the substrate. The $K_{\mathrm{M}}$ reported by Albernas-Carvajal et al. (2015), approximately $217.49 \mathrm{gL}^{-1}$, using the cellulolytic enzymes Novozymes Cellic ${ }^{\circledR}$ Ctec 2 and $\beta$-glucosidase with code NS50010 was much higher than the $K_{\mathrm{M}}$ obtained in the present work (a $K_{\mathrm{M}}$ of $23.5 \mathrm{gL}^{-1}$ ), which meant that the enzyme complex had a better affinity with the employed substrate.

For enzymatic reactions in general, Lehninger (1981) states that when [S] is much less than $K_{\mathrm{M}}$ (the value of [S] is $10 \mathrm{~g} / \mathrm{L}$ of glucans in this work), the reaction rate is of the first order concerning the substrate, which was assumed in the development of this model and gives a measure of its adequacy.

To determine the $K_{\mathrm{I}}$ inhibition constant, Eq. 4 is integrated under the initial and final conditions ( $G=G_{0}$ at $t=0$ and $G=G_{t}$ at $t=t$, respectively), obtaining Eqs. 5 and 6,

$$
\frac{t}{0.9(G-G o)}=\beta \frac{\ln \left[\left(G_{\infty}-G_{0}\right) /\left(G_{\infty}-G\right)\right.}{0.9\left(G-G_{0}\right)}-\gamma
$$

where

$$
\begin{aligned}
& \beta=\frac{K_{M}}{k E_{0}} \frac{1}{K_{I}} G_{\infty}+\frac{K_{M}}{k E_{0}} \\
& \gamma=\frac{1}{0.9} \frac{K_{M}}{k E_{0}} \frac{1}{K_{I}}-\frac{1}{k E_{0}}
\end{aligned}
$$


For the three pulps, $K_{\mathrm{I}}$ was calculated through the nonlinear least-squares algorithm (solver) utilizing the graphically determined parameters $k$ and $K_{\mathrm{M}}$, until the lowest average absolute error was achieved. The $K_{\mathrm{I}}$ values obtained for pulps 1,2 , and 3 were $2.9 \mathrm{gL}^{-1}, 3.1$ $\mathrm{gL}^{-1}$, and $6.6 \mathrm{gL}^{-1}$, respectively. The agreement of the model to the experimental data is presented in Fig. 5.

The resulting $K_{\mathrm{I}}$ is comparable with the value obtained by Albernas-Carvajal et al. (2015), who obtained a $K_{\mathrm{I}}$ of $32.64 \mathrm{gL}^{-1}$ when employing a pseudo-homogeneous Michaelis-Menten model for the enzymatic hydrolysis of pretreated bagasse. Li et al. (2004) studied the enzymatic hydrolysis kinetics of various pulps treated with continuous ultrasonic irradiation and Cellulase (Meicelase) from Trichoderma viride, obtaining a $K_{\mathrm{I}}$ value of $0.704 \mathrm{gL}^{-1}$. This behavior demonstrated that the value of $K_{\mathrm{I}}$ was independent of the operating variables but changed when the enzyme or the substrate was changed, so the whole procedure must be repeated.

Compared with the constants found by Li et al. (2004) using NUKP (unbleached kraft pulp from a coniferous tree), the reaction in this work was slow. The reason for this is that the constant $k$ is higher, and the $\mathrm{K}_{\mathrm{I}}$ and $\mathrm{K}_{\mathrm{M}}$ are both lower, yielding a lower $\mathrm{d} G / \mathrm{d} t$.

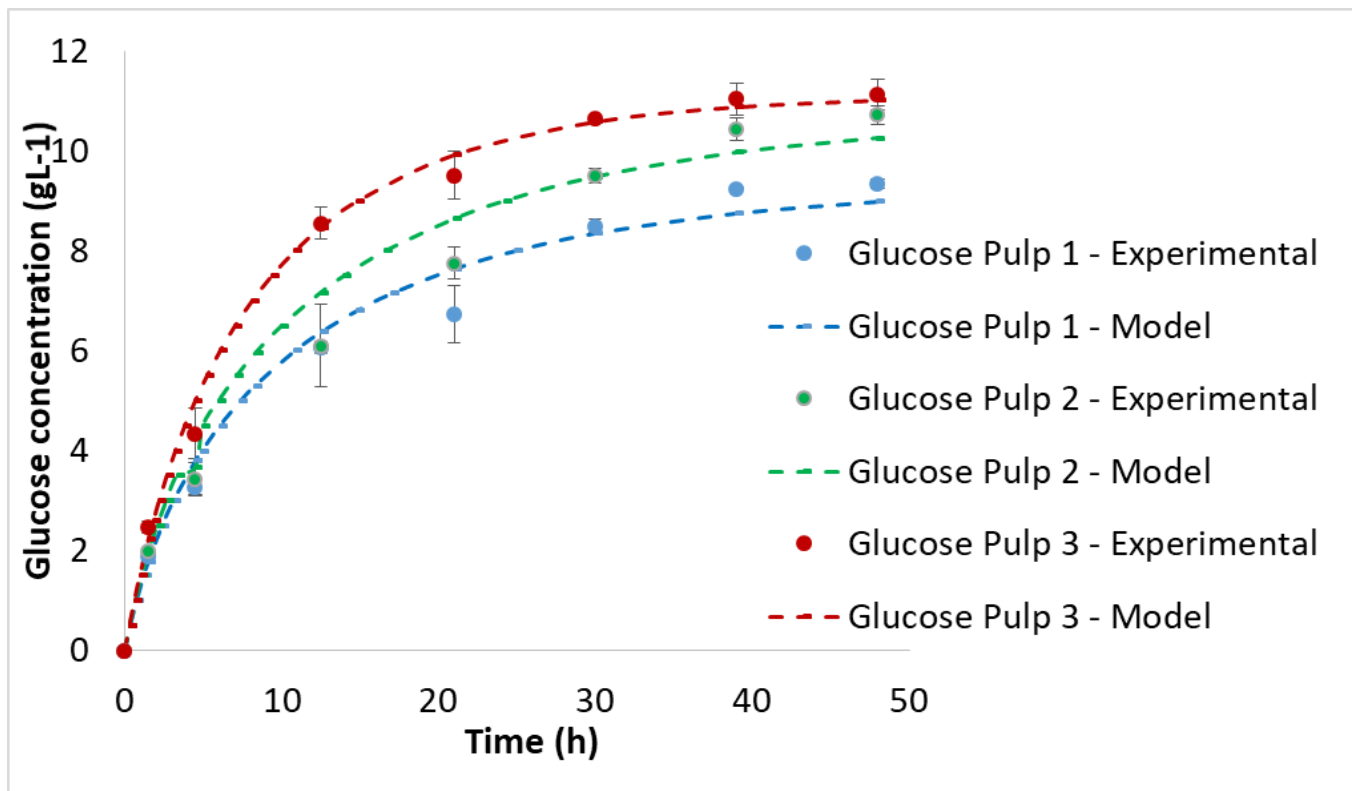

Fig. 5. Glucose concentration from the enzymatic hydrolysis of pulps 1, 2, and 3 (the experimental data is represented by points and the theoretical predictions by lines)

The equilibrium constant $K$ was defined to predict the total reducing sugars concentration $T$ from the modeled glucose data obtained for each pulp from the total reducing sugars and glucose concentrations data, as shown in Eq. 7,

$$
K=G / T-G
$$

where $K$ is the equilibrium constant, $G$ is the glucose concentration $\left(\mathrm{gL}^{-1}\right)$, and $T$ is the total reducing sugars $\left(\mathrm{gL}^{-1}\right)$.

Rearranging the equation, $K$ can be obtained from the slope of the experimental data line of the total reducing sugars and glucose concentrations, as shown in Eq. 8,

$$
G / T=K /(K+1)
$$




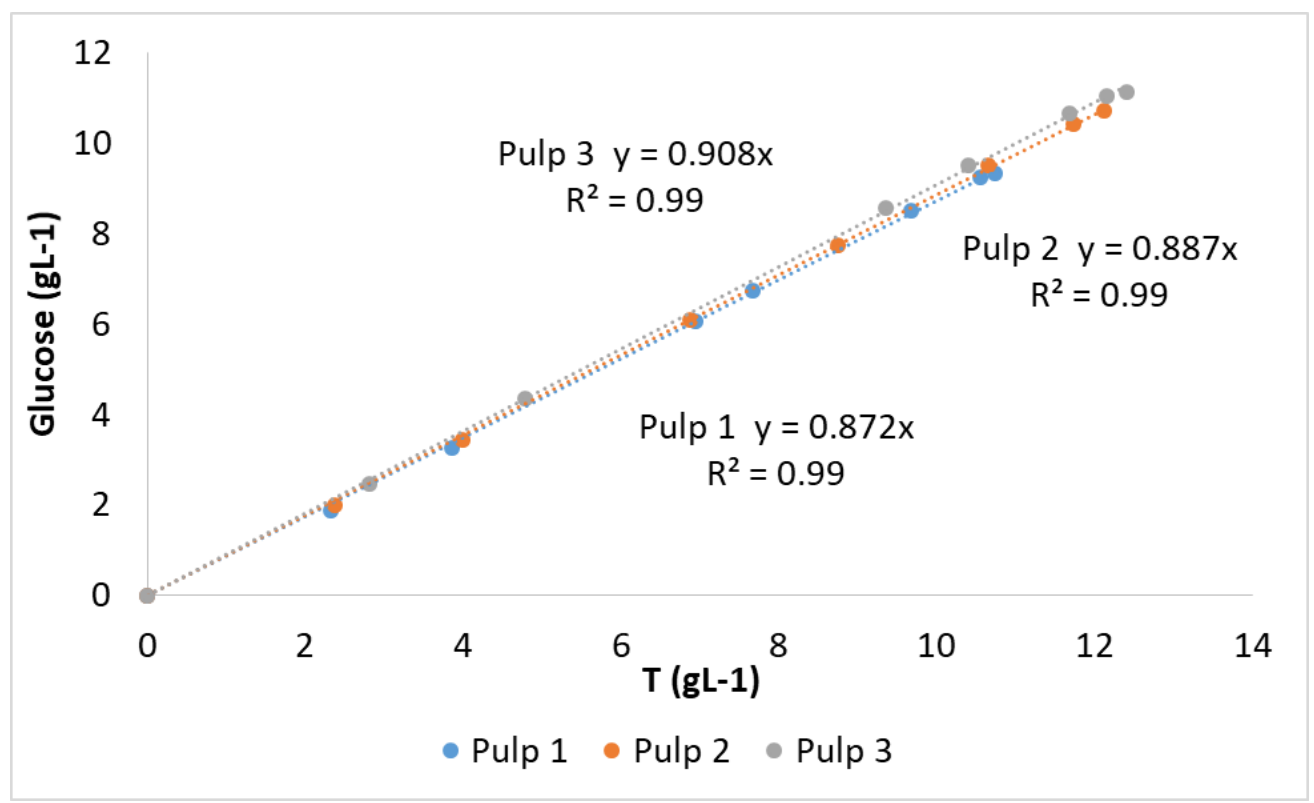

Fig. 6. Determination of the equilibrium constant $K$

Table 2 shows a summary of the kinetic parameters obtained for the three pulps.

Table 2. Kinetic Parameters for the Saccharification and Lignin Content of the Pulps

\begin{tabular}{|c|c|c|c|c|c|}
\hline Pulps & $K\left(\mathrm{~h}^{-1}\right)$ & $K_{\mathrm{M}}\left(\mathrm{gL}^{-1}\right)$ & $K_{l}\left(\mathrm{gL}^{-1}\right)$ & $K$ & Lignin (\%odm) \\
\hline 1 & 11.4 & 23.5 & 2.9 & 6.8 & 10.18 \\
\hline 2 & 11.4 & 23.5 & 3.1 & 7.8 & 7.04 \\
\hline 3 & 11.4 & 23.5 & 6.6 & 9.8 & 3.67 \\
\hline
\end{tabular}

The insoluble lignin content in the pulp shows a significant negative correlation with the inhibition constant $K_{\mathrm{I}}\left(\mathrm{R}^{2}=0.801\right)$ and the equilibrium constant $K\left(\mathrm{R}^{2}=0.972\right)$. Increasing the equilibrium constant and decreasing the lignin content implies a glucose increase concerning the total reducing sugars for each hydrolysis time. Furthermore, this agrees with the increase in the inhibition constant.

\section{Fermentation}

Bioethanol yield via the separate hydrolysis and fermentation (SHF) strategy

Pulp 3 was chosen for the SHF fermentation experiments due to its optimal saccharification performance. A maximal bioethanol concentration $\left(3.40 \mathrm{gL}^{-1} \pm 0.21 \mathrm{gL}^{-1}\right)$ was obtained at $13 \mathrm{~h}$, which was extremely close to the theoretical bioethanol concentration (Table 3). The achieved bioethanol yields are comparable with the results obtained by Kruyeniski (2017) using Pinus elliottii sawdust pretreated with soda-AQ (at a temperature of $170{ }^{\circ} \mathrm{C}$ for 140 minutes with $55.2 \mathrm{~g} / \mathrm{L}$ of $\mathrm{NaOH}, 0.1 \%$ of AQ, and RLM 5/1) with Saccharomyces cerevisiae (ethanol yield of 84.1\%). Cotana et al. (2014) also reached yields between $80.8 \%$ and $96.1 \%$ via SHF using steam-exploded pine, employing Cellic ${ }^{\circledR}$ Ctec 2 and Saccharomyces cerevisiae. Bahmani et al. (2016) reported ethanol yields of approximately $22.1 \%$ from the enzymatic hydrolysis of pine sawdust pretreated 
with an anaerobic digestion process. Tian et al. (2016) obtained a yield of $46.6 \%$ using Pinus strobus L., pretreated with an organic electrolyte solution, via SHF, using Cellic ${ }^{\circledR}$ Ctec2 and Saccharomyces cerevisiae.

Table 3. Bioethanol Yield via the Separate Hydrolysis and Fermentation (SHF) Strategy Applied to Pulp 3

\begin{tabular}{|c|c|c|c|}
\hline \multirow{2}{*}{ SHF Strategy } & \multicolumn{3}{|c|}{ Time $(\mathrm{h})$} \\
\hline & 13 & 20 & 24 \\
\hline Bioethanol concentration $\left(\mathrm{gL}^{-1}\right)$ & $3.40 \pm 0.21$ & $3.23 \pm 0.17$ & $3.23 \pm 0.21$ \\
\hline CV (\%) & 6.3 & 5.3 & 6.4 \\
\hline$Y_{\mathrm{P} / \mathrm{T}}(\%)$ & 89.3 & 84.8 & 84.8 \\
\hline Bioethanol productivity $\left(\mathrm{gL}^{-1} \mathrm{~h}^{-1}\right)$ & 0.26 & 0.16 & 0.13 \\
\hline $\begin{array}{l}\text { Glucose initial concentration is } \\
\text { fermentation yield; and CV (\%) }\end{array}$ & Theoreti & $\begin{array}{l}\text { ethanol is } \\
\mathrm{n}\end{array}$ & )$; Y_{\mathrm{P} / \mathrm{T}}(\%)$ \\
\hline
\end{tabular}

Bioethanol yield via the simultaneous saccharification and fermentation (SSF) strategy

During the SSF process, the glucose released by the enzymatic complex during hydrolysis is directly metabolized to ethanol by the yeasts, consuming glucose from the medium, producing a decrease in the end-product inhibition, a total process time reduction, and higher ethanol productivities (Mendes et al. 2020).

The results shown in Table 4 are comparable with those of Valenzuela et al. (2016), who reached a bioethanol yield of $80.2 \%$ using radiata pine with an organosolv pretreatment (using a $50 \%$ to $50 \%$ v/v ratio of ethanol to water, $1.1 \%$ w/w of $\mathrm{H}_{2} \mathrm{SO}_{4}$, at a temperature of $189{ }^{\circ} \mathrm{C}$ for $8 \mathrm{~min}$ ), using an SSF process under similar conditions and the same microorganisms. Similarly, Araque et al. (2008) reached a 99.5\% bioethanol yield using the SSF strategy with radiata pine chips with an acetone-water organosolv pretreatment (at a temperature of $195{ }^{\circ} \mathrm{C}$ for $5 \mathrm{~min}$ at a $\mathrm{pH}$ of $2.0 \mathrm{in}$ an acetone:water ratio of $1: 1)$.

Table 4. Bioethanol Yields of Pulps 1, 2, and 3 via the Simultaneous Saccharification and Fermentation (SSF) Strategy

\begin{tabular}{|c|c|c|c|c|c|c|}
\hline Simultaneous Saccharification and & \multicolumn{7}{|c|}{ Time $(\mathrm{h})$} \\
\cline { 2 - 7 } Fermentation (SSF) & 4 & 15 & 21 & 26 & 49 & 72 \\
\hline Theoretical bioethanol $\left(\mathrm{gL}^{-1}\right)$ & 5.68 & 5.68 & 5.68 & 5.68 & 5.68 & 5.68 \\
\hline \multirow{2}{*}{ Ethanol produced from pulp 1 $\left(\mathrm{gL}^{-1}\right)$} & $1.78 \pm$ & $2.84 \pm$ & $3.60 \pm$ & $4.27 \pm$ & $5.08 \pm$ & $5.25 \pm$ \\
& 0.12 & 0.30 & 0.40 & 0.01 & 0.30 & 0.24 \\
\hline$Y_{\mathrm{P} / \mathrm{T}}(\%)$ & 31.30 & 49.90 & 63.40 & 75.20 & 89.40 & 92.50 \\
\hline$P_{\mathrm{P} / \mathrm{t}}\left(\mathrm{gL}^{-1} \mathrm{~h}^{-1}\right)$ & 0.44 & 0.19 & 0.18 & 0.16 & 0.10 & 0.07 \\
\hline Glucose equivalent $\left(\mathrm{gL}^{-1}\right)$ & 3.48 & 5.56 & 7.05 & 8.36 & 9.94 & 10.27 \\
\hline Ethanol produced from pulp 2 $\left(\mathrm{gL}^{-1}\right)$ & $1.78 \pm$ & $3.26 \pm$ & $3.54 \pm$ & $4.46 \pm$ & $4.99 \pm$ & $5.65 \pm$ \\
\hline$Y_{\mathrm{P} / \mathrm{T}(\%)}$ & 0.07 & 0.35 & 0.19 & 0.11 & 0.13 & 0.17 \\
\hline$P_{\mathrm{P} / \mathrm{t}}\left(\mathrm{gL}^{-1} \mathrm{~h}^{-1}\right)$ & 31.40 & 57.40 & 62.40 & 78.50 & 87.90 & 99.50 \\
\hline Glucose Equivalent $\left(\mathrm{gL}^{-1}\right)$ & 3.48 & 6.38 & 6.93 & 8.73 & 9.77 & 11.06 \\
\hline Ethanol produced from pulp 3 $\left(\mathrm{gL}^{-1}\right)$ & $1.79 \pm$ & $4.50 \pm$ & $4.70 \pm$ & $4.82 \pm$ & $5.62 \pm$ & $5.68 \pm$ \\
& 0.18 & 0.49 & 0.24 & 0.08 & 0.09 & 0.04 \\
\hline$Y_{\mathrm{P} / \mathrm{(}(\%)}$ & 31.50 & 79.20 & 82.80 & 84.80 & 98.90 & 100 \\
\hline$P_{\mathrm{P} / \mathrm{t}}\left(\mathrm{gL}^{-1} \mathrm{~h}^{-1}\right)$ & 0.45 & 0.30 & 0.23 & 0.19 & 0.12 & 0.08 \\
\hline Glucose equivalent $\left(\mathrm{gL}^{-1}\right)$ & 3.50 & 8.81 & 9.20 & 9.43 & 11.00 & 11.12 \\
\hline Note: $Y_{\mathrm{P} / \mathrm{T}}(\%)$ is the fermentation yield & & & & & \\
\hline
\end{tabular}


The ethanol yield of Pulp 3 was $100 \% \pm 0.7 \%$, which was approximately $10 \%$ greater than the ethanol yield obtained via the SHF strategy $(89.3 \% \pm 0.8 \%)$, despite these last experiments being carried out under optimal temperature and $\mathrm{pH}$ conditions for both the enzymes and microorganisms. Concentrations at $72 \mathrm{~h}$ ranged from 5.25 to $5.68 \mathrm{gL}^{-1}$, close to the theoretical concentrations, with yields of $92.5 \%, 99.5 \%$, and $100 \%$ for pulps 1,2 , and 3 , respectively.

To evaluate the performance of the enzymatic complex used in the SSF process, because it works at a lower temperature $\left(37^{\circ} \mathrm{C}\right)$ than the optimum temperature of the saccharification process (SAC), the model obtained for the SAC process was applied, using the equivalent glucose parameter.

The equivalent glucose concentrations were calculated from the ethanol concentration data (Table 4). Figure 7 presents the experimental and model data. Table 5 shows the experimental results and those predicted by the model after $48 \mathrm{~h}$ and $72 \mathrm{~h}$ of treatment.

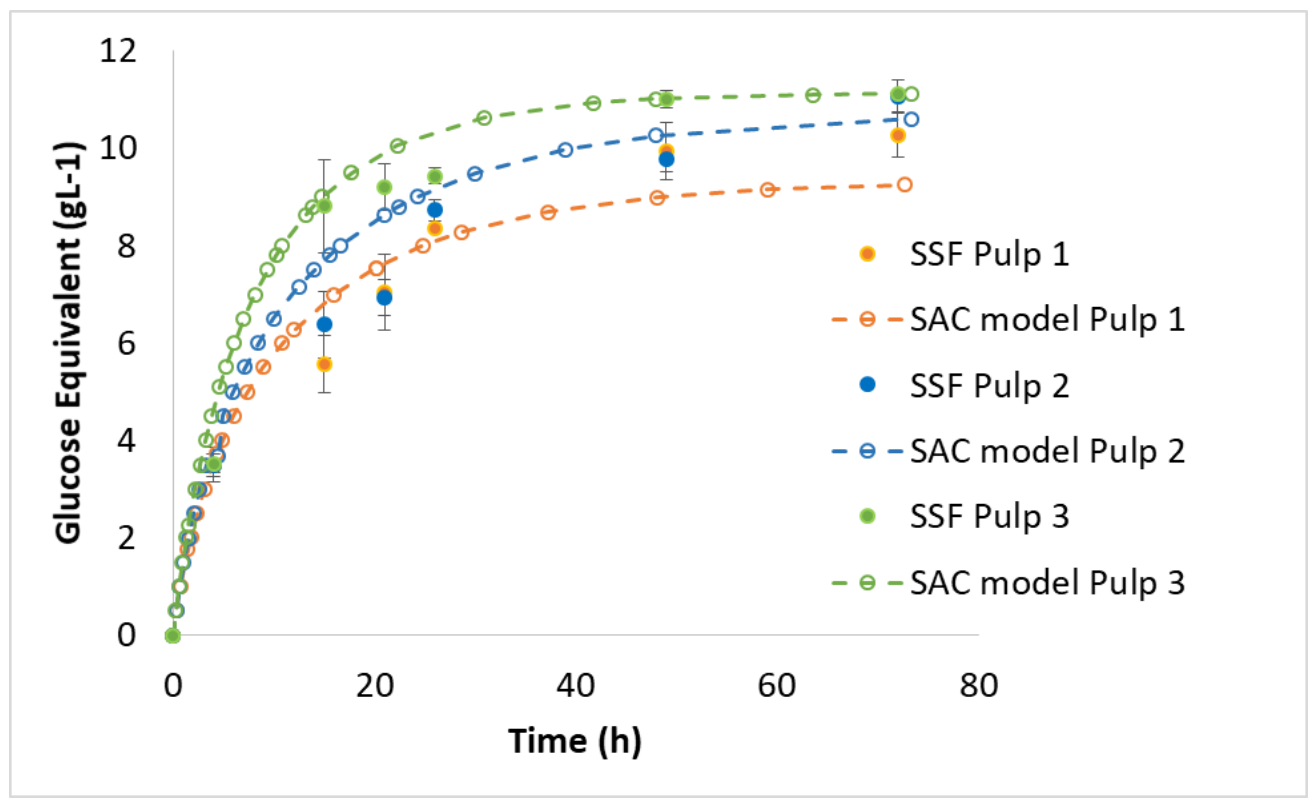

Fig. 7. The glucose concentration from saccharification (the experimental data is represented by points and the theoretical predictions by lines) Note: SAC is the saccharification process

Table 5. Experimental Glucose Equivalent for SSF and the Model Data of the Glucose Concentration from Saccharification at $48 \mathrm{~h}$ and $72 \mathrm{~h}$

\begin{tabular}{|c|c|c|c|c|c|c|}
\hline SSF Glucose $\left(\mathrm{gL}^{-1}\right)$ & $\begin{array}{c}48(\mathrm{~h}) \\
\text { Experimental }\end{array}$ & $\begin{array}{c}48(\mathrm{~h}) \\
\text { Model }\end{array}$ & $\begin{array}{c}\text { Error } \\
(\%)\end{array}$ & $\begin{array}{c}72(\mathrm{~h}) \\
\text { Experimental }\end{array}$ & $\begin{array}{c}72(\mathrm{~h}) \\
\text { Model }\end{array}$ & $\begin{array}{c}\text { Error } \\
(\%)\end{array}$ \\
\hline 1 & 9.94 & 9.01 & -9.40 & 10.27 & 9.25 & -10.00 \\
\hline 2 & 9.77 & 10.28 & 5.30 & 11.06 & 10.60 & -4.10 \\
\hline 3 & 11.00 & 11.02 & 0.20 & 11.12 & 11.12 & 0.00 \\
\hline
\end{tabular}

Figure 7 shows that the model obtained for the SAC process can be used for the SSF process, since it predicts the experimental data with a good fit. It also indicated that under the studied conditions, the enzyme complex does not present a lower yield. The errors obtained from applying this model, measured at 48 and $72 \mathrm{~h}$, were less than $10 \%$ (Table 5). 


\section{Separate Hydrolysis and Fermentation (SHF) vs. Simultaneous Saccharification and Fermentation (SSF)}

The SHF strategy has several advantages. First, the hydrolysis and fermentation processes can be carried out under optimal $\mathrm{pH}$ and temperature conditions, among others (Robak and Balcerek 2018). In addition, saccharification at the optimum temperature requires a lower enzymatic charge than the SSF process (Ishizaki and Hasumi 2014). However, for the SHF strategy, the fermentation is accomplished in a liquid broth facilitating the mass transfer and yeast recycling after fermentation (via filtration or centrifugation) (Galbe et al. 2011).

Its disadvantages are an increase in contaminants and the product inhibition effect, since the rate of hydrolysis limits cellulase activity because of the concentration of generated sugars (Robak and Balcerek 2018). The used complex (Cellic ${ }^{\circledR}$ Ctec 2) has a high proportion of $\beta$-glucosidase enzyme, ensuring the hydrolysis of cellobiose and small oligosaccharides (Verdecía and Diaz 2008). The use of cellulolytic complexes with higher $\beta$-glucosidase activities increases the hydrolysis yield because cellobiose inhibits the cellulolytic complex more than glucose (Pabón et al. 2020).

High gravity fermentation (VHG) is an alternative to optimize bioethanol production when using the SHF strategy. High gravity fermentation is a highly concentrated process in which yeast cells are exposed to high osmotic pressure at the beginning of the fermentation process, caused by the high sugar concentrations and ethanol accumulation. The ethanol accumulation, together with high levels of other toxic byproducts from the fermentation, becomes lethal to fermenting yeast cells, so the yeast strains used must be carefully selected to overcome the different stresses imposed during this process (Wang et al. 2007). Sugar cane molasses, starch, and lignocellulosic materials can be used as substrates (Balat and Balat 2009; Mussatto et al. 2010). The primary advantage of VHG technology is the production of a very high ethanol concentration (generally greater than $15 \% \mathrm{v} / \mathrm{v}$ ). This approach reduces the cost of the distillation stage, which is considered one of the primary limitations in the bioethanol industry. It has been reported that VHG (at 19\%) reduces the steam consumption to less than $1 \mathrm{~kg}$ of steam per $\mathrm{kg}$ of bioethanol. However, when combined with membrane separation (pervaporation of $25 \%$ of the fermenter broth), it achieves approximately $20 \%$ savings and considerably reduces the risk of inhibition in the fermenter (Kang et al. 2014).

Nevertheless, the simultaneous process seems the most feasible and cost-effective alternative to produce bioethanol because of the advantages in inhibitory products reduction and a single reactor use for the whole process, thus limiting the investment costs (Olofsson et al. 2008). Sugar monomers released during saccharification are immediately fermented by the microorganisms, decreasing the risk of microbial contamination (Robak and Balcerek 2018). In other words, the glucose is instantly fermented into bioethanol, regardless of the optimum temperature and $\mathrm{pH}$ parameters for both the hydrolysis and fermentation process (Wyman et al. 1992).

\section{CONCLUSIONS}

1. The type and conditions of the pretreatment applied to pine sawdust influenced the enzymatic hydrolysis performance due to the reduction in lignin content, which considerably improved the accessibility of the enzymes to the material, enhancing the digestibility of the cellulose. The most delignified pulp (a lignin content of 3\%)

Mendieta et al. (2021). "Pine hydrolysis, fermentation," BioResources 16(4), 7474-7491. 7486 
presented the highest enzymatic hydrolysis with a glucose production of $11.1\left(\mathrm{gL}^{-1}\right)$ in $48 \mathrm{~h}$.

2. The applied kinetic model showed good agreement with the experimental data. The Michaelis-Menten constant value for this substrate-enzyme complex was found to be $K_{\mathrm{M}}=23.5 \mathrm{gL}^{-1}$, which indicated that the enzyme complex had a good affinity with the employed substrate. The inhibition constant $\left(\mathrm{K}_{\mathrm{I}}\right)$ for pulp 1,2 , and 3 were $2.9 \mathrm{gL}^{-1}, 3.1$ $\mathrm{gL}^{-1}$, and $6.6 \mathrm{gL}^{-1}$, respectively, denoting the satisfactory performance of the used enzyme complex to carry out the saccharification process.

3. High bioethanol yields were obtained in this work using the SSF strategy for this high recalcitrant pine species pretreated via an organosolv-alkaline delignification treatment. In addition, the used enzyme complex showed good performance in the SSF process, despite using a lower temperature $\left(37^{\circ} \mathrm{C}\right)$ than optimal for the saccharification process.

4. Using $30.0 \mathrm{FPUg}^{-1}$ of substrate and $1 \%$ hydrolyzable cellulose at a temperature of 37 ${ }^{\circ} \mathrm{C}$, a $\mathrm{pH}$ of 5.0, the obtained average bioethanol concentrations via SSF were $92.5 \%$, $99.5 \%$, and $100 \%$ for pulps 1,2 , and 3, respectively.

\section{ACKNOWLEDGMENTS}

The authors gratefully acknowledge the support of the UNaM (National University of Misiones, Argentina) and the CONICET (National Council of Scientific and Technical Research, Argentina), as well as the ValBio-3D "Valorization of residual biomass for advanced 3D materials" project (Grant No. ELAC2015/T03-0715) (Ministry of Science, Technology, and Productive Innovation of Argentina) for the financial support.

\section{REFERENCES CITED}

Adney, B., and Backer, J. (2008). Measurement of Cellulose Activities (NREL/TP-51042628), National Renewable Energy Laboratory, Golden, CO.

Albernas-Carvajal, Y., Corsano, G., Garriga, L. M., Herrero, R. S., and Suárez, E. G. (2015). "Estudio de la cinética de la hidrólisis enzimática del bagazo pretatado [Study of enzymatic hydrolysis kinetics of pre-treated bagasse]," Afinidad 72(570), 127-132.

Alzate, C. A. C., and Toro, O. J. S. (2006). "Energy consumption analysis of integrated flowsheets for production of fuel ethanol from lignocellulosic biomass," Energy 31(13), 2447-2459. DOI: 10.1016/j.energy.2005.10.020

Araque, E., Parra, C., Freer, J., Contreras, D., Rodríguez, J., Mendonça, R., and Baeza, J. (2008). "Evaluation of organosolv pretreatment for the conversion of Pinus radiata D. Don to ethanol," Enzyme and Microbial Technology 43(2), 214-219. DOI: 10.1016/j.enzmictec.2007.08.006

Area, M. C., and Vallejos, M. E. (2012). Biorrefinería a Partir de Residuos Lignocelulósicos. Conversión de Residuos a Productos de alto Valor [Biorefinery from lignocellulosic waste: Conversion of waste to high value products], Editorial Académica Española, Riga, Latvia.

Arismendy, A. M., Sequeira, M. J., Felissia, F. E., Area, C. M., and Chamorro, E. R. 
(2018). "Evaluación de cepas fermentativas en la hidrólisis y fermentación simultáneas (SSF) de cascarilla de arroz para la producción de bioetanol [Evaluation of fermentative strains in the simultaneous hydrolysis and fermentation (SSF) of rice husk for the production of bioethanol]," Revista Tecnología y Ciencia 30, 357-363.

Bahmani, M. A., Shafiei, M., and Karimi, K. (2016). "Anaerobic digestion as a pretreatment to enhance ethanol yield from lignocelluloses," Process Biochemistry 51(9), 1256-1263. DOI: 10.1016/j.procbio.2016.05.012

Balat, M. (2011). "Production of bioethanol from lignocellulosic materials via the biochemical pathway: A review," Energy Conversion and Management 52(2), 858875. DOI: 10.1016/j.enconman.2010.08.013

Balat, M., and Balat, H. (2009). "Recent trends in global production and utilization of bio-ethanol fuel," Applied Energy 86(11), 2273-2282. DOI: 10.1016/j.apenergy.2009.03.015

Brodin, M., Vallejos, M., Opedal, M. T., Area, M. C., and Chinga-Carrasco, G. (2017). "Lignocellulosics as sustainable resources for production of bioplastics - A review," Journal of Cleaner Production 162, 646-664. DOI: 10.1016/j.jclepro.2017.05.209

Cekmecelioglu, D., and Uncu, O. N. (2013). "Kinetic modeling of enzymatic hydrolysis of pretreated kitchen wastes for enhancing bioethanol production," Waste Management 33(3), 735-739. DOI: 10.1016/j.wasman.2012.08.003

Chang, V. S., and Holtzapple, M. T. (2000). "Fundamental factors affecting biomass enzymatic reactivity," Applied Biochemistry and Biotechnology 84, 5-37. DOI: 10.1385/ABAB:84-86:1-9:5

Chu, Q., Li, X., Ma, B., Xu, Y., Ouyang, J., Zhu, J., Yu, S., and Yong, Q. (2012). "Bioethanol production: An integrated process of low substrate loading hydrolysishigh sugars liquid fermentation and solid state fermentation of enzymatic hydrolysis residue," Bioresource Technology 123, 699-702. DOI: 10.1016/j.biortech.2012.07.118

Clauser, N. M., González, G., Mendieta, C. M., Kruyeniski, J., Area, M. C., and Vallejos, M. E. (2021). "Biomass waste as sustainable raw material for energy and fuels," Sustainability 13(2), 794. DOI: 10.3390/su13020794

Cotana, F., Cavalaglio, G., Gelosia, M., Nicolini, A., Coccia, V., and Petrozzi, A. (2014). "Production of bioethanol in a second generation prototype from pine wood chips," Energy Procedia 45, 42-51. DOI: 10.1016/j.egypro.2014.01.006

Das, P., Stoffel, R. B., Area, M. C., and Ragauskas, A. J. (2019). "Effects of one-step alkaline and two-step alkaline/dilute acid and alkaline/steam explosion pretreatments on the structure of isolated pine lignin," Biomass and Bioenergy 120, 350-358. DOI: 10.1016/j.biombioe.2018.11.029

Dowe, N., and McMillan, J. (2008). SSF Experimental Protocols-Lignocellulosic Biomass Hydrolysis and Fermentation (NREL/TP-510-42630), National Renewable Energy Laboratory, Golden, CO.

Galbe, M., Wallberg, O., and Zacchi, G. (2011). "6.47 - Techno-economic aspects of ethanol production from lignocellulosic agricultural crops and residues," in: Comprehensive Biotechnology (Second Edition), M. Moo-Young (ed.), Pergamon Press, Oxford, United Kingdom, pp. 615-628.

Hahn-Hägerdal, B., Galbe, M., Gorwa-Grauslund, M. F., Lidén, G., and Zacchi, G. (2006). "Bio-ethanol - The fuel of tomorrow from the residues of today," Trends in Biotechnology 24(12), 550-556. DOI: 10.1016/j.tibtech.2006.10.004

Hou, J., Tang, J., Chen, J., Deng, J., Wang, J., and Zhang, Q. (2019). "Evaluation of 
inhibition of lignocellulose-derived by-products on bioethanol production by using the QSAR method and mechanism study," Biochemical Engineering Journal 147, 153-162. DOI: 10.1016/j.bej.2019.04.013

Imlauer, C. M., Area, M. C., Raffaeli, N., and Felissia, F. E. (2021). "Study on soda/ethanol delignification of pine sawdust for a biorefinery," Unpublished.

Ishizaki, H., and Hasumi, K. (2014). "Chapter 10 - Ethanol production from biomass," in: Research Approaches to Sustainable Biomass Systems, S. Tojo and T. Hirasawa (ed.), Academic Press, Cambridge, MA, pp. 243-258.

Kang, Q., Appels, L., Baeyens, J., Dewil, R., and Tan, T. (2014). "Energy-efficient production of cassava-based bio-ethanol," Advances in Bioscience and Biotechnology 5(12), 925-939. DOI: 10.4236/abb.2014.512107

Kruyeniski, J. (2017). Influencia del Pretratamiento de Residuos Forestoindustriales sobre la Producción de Bioetanol [Influence of Pretreatment of Forestry-Industrial Waste on Bioethanol Production], Ph.D. Disseration, National University of Misiones, Posadas, Argentina

Kruyeniski, J., Ferreira, P. J. T., Carvalho, M. d. G. V. S., Vallejos, M. E., Felissia, F. E., and Area, M. C. (2019). "Physical and chemical characteristics of pretreated pine sawdust and its enzymatic hydrolysis," Industrial Crops and Products 130, 528-536. DOI: 10.1016/j.indcrop.2018.12.075

Laharrague, N. (2018). Censo Nacional de Aserraderos, Dirección Nacional de Desarrollo Foresto Industrial, Misiones, Argentina.

Lehninger, A. (1981). Principios de Bioquímica [Principles of Biochemistry], Second Edition, Editorial Pueblo y Educación, Chapter 8, 189-218.

Li, C., Yoshimoto, M., Tsukuda, N., Fukunaga, K., and Nakao, K. (2004). “A kinetic study on enzymatic hydrolysis of a variety of pulps for its enhancement with continuous ultrasonic irradiation," Biochemical Engineering Journal 19(2), 155-164. DOI: 10.1016/j.bej.2003.12.010

Matsuura, M., Sasaki, J., and Murao, S. (1995). "Studies on $\beta$-glucosidases from soybeans that hydrolyze daidzin and genistin : Isolation and characterization of an isozyme," Biosciencie, Biotechnology \& Biochemistry 59(9), 1623-1627. DOI: 10.1271/bbb.59.1623

Mendes-Texeira, C. V., Vergara, V., Carbajo, J. M., Villar, J. C., Rocha, J. M., Videira, M. (2020). "Bioconversion of pine stumps to ethanol: pretreatment and simultaneous saccharification and fermentation," Holzforschung 74(2), 212-216. DOI: https://doi.org/10.1515/hf-2018-0126

Mendieta, C. M., Vallejos, M. E., Felissia, F. E., Chinga-Carrasco, G., and Area, M. C. (2019). "Review: Bio-polyethylene from wood wastes," Journal of Polymers and the Environment 28(1), 1-16. DOI: 10.1007/s10924-019-01582-0

Mendieta, C. M., Cardozo, R. E., Felissia, F. E., Clauser, N. M., Vallejos, M. E., and Area, M. C. (2021). "Bioconversion of wood waste to bio-ethylene: A review," BioResources 16(2), 4411-4437. DOI: 10.15376/biores.16.2.Mendieta

Mussatto, S. I., Dragone, G., Guimarães, P. M. R., Silva, J. P. A., Carneiro, L. M., Roberto, I. C., Vicente, A., Domingues, L., and Teixeira, J. A. (2010). “Technological trends , global market , and challenges of bio-ethanol production," Biotechnology Advances 28(6), 817-830. DOI: 10.1016/j.biotechadv.2010.07.001

Olofsson, K., Bertilsson, M., and Lidén, G. (2008). “A short review on SSF - An interesting process option for ethanol production from lignocellulosic feedstocks," Biotechnology for Biofuels 1, 1-14. DOI: 10.1186/1754-6834-1-7 
Olsson, L., and Hahn-Hägerdal, B. (1996). "Fermentation of lignocellulosic hydrolysates for ethanol production," Enzyme and Microbial Technology 18(5), 312-331. DOI: 10.1016/0141-0229(95)00157-3

Pabón, A. M. A., Felissia, F. E., Mendieta, C. M., Chamorro, E., and Area, M. C. (2020). "Improvement of bioethanol production from rice husks," Cellulose Chemistry and Technology 54(7-8), 689-698. DOI: 10.35812/CelluloseChemTechnol.2020.54.68

Pabón, A. M. A., Retrepo, A. F. V., Zapata, W. A., Chamorro, E. R., and Area, M. C. (2019). "Optimización de la hidrólisis enzimática de la cascarilla de arroz [Optimization of the enzymatic hydrolysis of rice husk]," Repositorio Español de Ciencia y Tecnología 32(1), 64-70. DOI: 10.36995/j.recyt.2019.32.010

Posen, I. D., Griffin, W. M., Matthews, H. S., and Azevedo, I. L. (2014). "Changing the renewable fuel standard to a renewable material standard: Bioethylene case study," Environmental Science and Technology 49(1), 93-102. DOI: 10.1021/es503521r

Resch, M. G., Baker, J. O., and Decker, S. R. (2015). Low Solids Enzymatic Saccharification of Lignocellulosic Biomass (NREL/TP-5100-63351), National Renewable Energy Laboratory, Golden, CO.

Robak, K., and Balcerek, M. (2018). "Review of second generation bioethanol production from residual biomass," Food Technology and Biotechnology 56(2), 174187. DOI: $10.17113 / \mathrm{ftb} .56 .02 .18 .5428$

Rodríguez, M. D., Castrillo, M. L., Velázquez, J. E., Kramer, G. R., Sedler, C., Zapata, P. D., and Villalba, L. (2017). "Obstención de azucares fermentables a partir de aserrín de pino pretratado secuencialmente con ácido-base [Obtaining fermentable sugars from pine saw dust sequentially pre-treated with acid-base]," Revista Internacional de Contaminación Ambiental 33(2), 317-324. DOI: 10.20937/RICA.2017.33.02.12

Roskoski, R. (2015). "Michaelis-Menten kinetics," in: Reference Module in Biomedical Sciences, R. Roskoski (ed.), Elsevier, Amsterdam, Netherlands, pp. 1-10.

Sannigrahi, P., Miller, S. J., and Ragauskas, A. J. (2010). "Effects of organosolv pretreatment and enzymatic hydrolysis on cellulose structure and crystallinity in loblolly pine," Carbohydrate Research 345(7), 965-970. DOI:

10.1016/j.carres.2010.02.010

Schenck, A. v., Berglin, N., and Uusitalo, J. (2013). "Ethanol from Nordic wood raw material by simplified alkaline soda cooking pre-treatment," Applied Energy 102, 229-240. DOI: 10.1016/j.apenergy.2012.10.003

Sluiter, A., Hames, B., Ruiz, R., Scarlata, C., Sluiter, J., Templeton, D., and Crocker, D. (2004). Determination of Structural Carbohydrates and Lignin in Biomass (NREL/ TP-510-42618), National Renewable Energy Laboratory, Golden, CO.

Sluiter, A., Ruiz, R., Scarlata, C., Sluiter, J., and Templeton, D. (2008). Determination of Extractives in Biomass (NREL/TP-510-42619), National Renewable Energy Laboratory, Golden, CO.

Taherzadeh, M. J., and Karimi, K. (2007). "Enzyme-based hydrolysis processes for ethanol from lignocellulosic materials: A review," BioResources 2(4), 707-738. DOI: 10.15376/biores.2.4.707-738

Tian, X., Rehmann, L., Xu, C. C., Fang, Z. (2016). "Pretreatment of eastern white pine (Pinus strobes L.) for enzymatic hydrolysis and ethanol production by organic electrolyte solutions," ACS Sustainable Chemistry \& Engineering 4(5), 2822-2829. DOI: 10.1021/acssuschemeng.6b00328

Tomczak, J. M., and Węglarz-Tomczak, E. (2019). "Estimating kinetic constants in the Michaelis-Menten model from one enzymatic assay using Approximate Bayesian 
Computation," FEBS Letters 593(19), 2742-2750. DOI: 10.1002/1873-3468.13531

Valenzuela, R., Priebe, X., Troncoso, E., Ortega, I., Parra, C., and Freer, J. (2016). "Fiber modifications by organosolv catalyzed with $\mathrm{H}_{2} \mathrm{SO}_{4}$ improves the SSF of Pinus radiata," Industrial Crops \& Products 86, 79-86. DOI:

10.1016/j.indcrop.2016.03.037

Vallejos, M. E., Kruyeniski, J., and Area, M. C. (2017). "Second-generation bioethanol from industrial wood waste of South American species," Biofuel 4(3), 654-667. DOI: 10.18331/BRJ2017.4.3.4

Verdecía, J. F. M., and Diaz, M. S. (2008). "General technological aspects for the conversion to ethanol of the lignocellulosic biomass," Tecnología Química 28(3), 6370. DOI: $10.1590 / 2224-6185.2008 .3 . \% 25 x$

Wang, F.-Q., Gao, C.-J., Yang, C.-Y., and Xu, P. G. (2007). "Optimization of an ethanol production medium in very high gravity fermentation," Biotechnol Letters 29, 233 236. DOI: $10.1007 / \mathrm{s} 10529-006-9220-6$

Wyman, C. E., Spindler, D. D., and Grohmann, K. (1992). "Simultaneous saccharifaction and fermentation of several lignocellulosic feedstocks to fuel ethanol," Biomass and Bioenergy 3(5), 301-307. DOI: 10.1016/0961-9534(92)90001-7

Yang, B., Dai, Z., Ding, S.-Y., and Wyman, C. E. (2011). "Enzymatic hydrolysis of cellulosic biomass," Biofuels 2(4), 421-449. DOI: 10.4155/bfs.11.116

Yang, C.-Y., and Fang, T. J. (2015). "Kinetics of enzymatic hydrolysis of rice straw by the pretreatment with a bio-based basic ionic liquid under ultrasound," Process Biochemistry 50(4), 1-7. DOI: 10.1016/j.procbio.2015.01.013

Yu, Z., Jameel, H., Chang, H., and Park, S. (2011). "The effect of delignification of forest biomass on enzymatic hydrolysis," Bioresource Technology 102(19), 9083-9089. DOI: 10.1016/j.biortech.2011.07.001

Zhu, M. J., Zhu, Z. S., and Li, X. H. (2011). "Bioconversion of paper sludge with low cellulosic content to ethanol by separate hydrolysis and fermentation," African Journal of Biotechnology 10(66), 15072-15083. DOI: 10.5897/AJB11.1644

Article submitted: August 4, 2021; Peer review completed: September 11, 2021; Revised version received and accepted: September 16, 2021; Published: September 23, 2021.

DOI: 10.15376/biores.16.4.7474-7491 